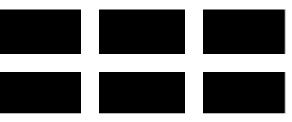

ThE WiLliam DAVIDSON InstituTE AT THE UNIVERSITY OF MICHIGAN BUSINESS SCHOOL

\title{
On Types of Trade, Adjustment of Labor and Welfare Gains During Asymmetric Liberalizations
}

\author{
By: Yener Kandogan
}

William Davidson Working Paper Number 568

May 2003 


\title{
On Types of Trade, Adjustment of Labor and Welfare Gains During Asymmetric Liberalizations
}

\author{
Yener Kandogan ${ }^{\dagger}$
}

University of Michigan-Flint

\begin{abstract}
This paper modifies the two-industry, two-country Heckscher-Ohlin model with intermediate goods to decompose trade into its horizontal and vertical intra-industry, as well as inter-industry parts. Acknowledging that liberalization affects each type of trade differently, and that changes in each imply labor adjustment of different magnitudes, the paper analyzes the effects of widely observed asymmetries in liberalization policies. The paper concludes with the implications of the model for the liberalization between the East and the West through the Europe Agreements.
\end{abstract}

JEL classification: $F 11, F 15$

Keywords: Trade types, Adjustment, Asymmetric Liberalization, Europe Agreements

\footnotetext{
${ }^{\dagger}$ Address: School of Management, University of Michigan-Flint, 303 E. Kearsley, Flint MI 48502 E-mail: yener@umflint.edu Phone: (810) 2376675
} 


\section{Introduction}

Since the fall of socialism in Eastern Europe, there has been a lot of effort to integrate Central and Eastern European countries (CEEC) to Western Europe. In particular, the Europe Agreements (EA) -signed in the early 1990s- are seen as dramatic improvements in the EU's trade policy towards CEEC (Kaminski 1995). It is argued that they provide rapid extensions of liberalized market access for industrial imports from CEEC. Furthermore, they are seen as catalysts for exploiting highly skilled but cheap labor in CEEC, and the proximity between the EU and CEEC, to outsource certain stages of production.

However, the EA have certain characteristics, which might let down these expectations. These agreements are country-asymmetric: Liberalization is slower on the part of CEEC than the EU. About $70 \%$ of EU imports were freed upon signature; all EU imports were scheduled to be free by the end of 1997. On the other hand, 10-20\% of CEEC imports were freed upon signature; all CEEC imports were scheduled to be free in 2002. Apart from this, the EA are also industryasymmetric because of the industries that are kept out of liberalization. These "sensitive" industries are textiles and apparel, iron and steel, and chemicals. It is claimed that CEEC have comparative advantage in these industries (Winters 1993; Messerlin 1993). They take about 20\% of the manufacturing output in the CEEC.

These country- and industry-asymmetries are not unique to the EA. Actually, one might easily claim that symmetric liberalizations, where both partners liberalize all industries at the same pace, are rare. The provisions given to developing countries under GATT, and the trade relations of the EU with their former colonies can be counted as other examples of asymmetric liberalizations.

This paper analyzes the effects of asymmetries on types of trade, adjustment in labor markets, and gains in welfare. It modifies the two-industry, two-country Heckscher-Ohlin model to get three different types of trade: A CES-type utility function is assumed so that consumers in each country consume not only the domestic product but also its variety produced by the partner 
country. This will result in horizontal intra-industry trade. Furthermore, an intermediate product is added to each industry, and joint production is allowed. In this framework, production process can be internationally fragmented: Producers now have the option of buying the intermediate from the partner, and sell back the finished product, if prices among other things allow. This will lead to vertical intra-industry trade. Bhagwati and Dehejia (1994), Krugman (1996), Leamer (1996) and Antweiler and Trefler (1997) refer to the importance of this international disintegration of production during liberalization. Finally, the usual factor endowment differences between partners will cause inter-industry trade.

Decomposing trade into its parts is important since liberalization affects each type of trade differently, and changes in each imply labor adjustment and welfare gains of different magnitudes. Especially, decomposing intra-industry into its vertical and horizontal parts is critical in terms of its implications for adjustment in labor. An adjustment occurs since the factors used in the production of a good are specific, and cannot be used in the production of other goods without transformation. In horizontal IIT, similar varieties are exchanged, whereas vertical IIT is the exchange of different products in the same industry due to vertical disintegration of production process. In other words, in vertical IIT, the production of commodities traded requires a different set of skills. Reallocating labor into jobs requiring different skills is costly, even if the jobs in question are in the same industry. Therefore, vertical-IIT changes involve some labor adjustment, and thus they are costly, but probably less costly than inter-industry-type changes. Analyzing only the inter-industry trade would underestimate the magnitude of adjustment in labor markets and the implied adjustment costs.

In Section 2, I present the model. The labor adjustment implications and the associated welfare gains of different liberalization policies are examined in Section 3, as well as the effects of differences in size, and in factor abundance. The paper concludes with the implications of the model to the European Union's integration with Central and Eastern European countries. 


\section{The model}

There are two factors of production: high- and low-skill labor, $L_{h}$ and $L_{l}$. They are used in producing four goods in two industries: goods $x_{1}$ and $y_{1}$ in industry 1 , and goods $x_{2}$ and $y_{2}$ in industry 2. An industry is defined as a group of goods with input-output relations. In this model, each good $y$ is an intermediate good used in the production of good $x$ in the same industry. Intermediate goods can be consumed directly as well. The production functions have constant returns to scale, represented by the following unit-input requirements:

$$
a_{f g i}\left(w_{h}, w_{l}\right)=\frac{L_{f g i}}{Q_{g i}}, a_{y x i}=\frac{Q_{y x i}}{Q_{x i}}, f \in\{h, l\}, g \in\{x, y\} \text {, and } i \in\{1,2\}
$$

where $L_{f g i}$ is the amount of factor $f$ used in the production of good $g$ in industry $i . Q_{g i}$ is the amount of good $g$ production in industry $i . a_{y x i}$ is the per unit requirement of the intermediate good $y$ in the production of the final good $x$ in industry $i . w_{h}$ and $w_{l}$ are wages of high- and lowskill labor, respectively.

Production technologies respond to changes in wages in the following way:

$$
\eta_{m f}^{g i}=\frac{\partial a_{m g i}}{\partial w_{f}} \frac{w_{f}}{a_{m g i}}, m \& f \in\{h, l\}, g \in\{x, y\}, \text { and } i \in\{1,2\}
$$

where $\eta_{m f}^{g i}$ is the labor demand elasticity for high- or low-skill labor in good $g$ industry $i$.

Using the identity $\sum_{f} \eta_{m f}^{g i}=0$ and assuming $\eta_{h h}^{g i}=\eta_{l l}^{g i}=\eta \forall g, \forall i$ for simplicity, unit factor requirements can be represented as follows:

$$
a_{h g i}=c_{h g i}\left(\frac{w_{h}}{w_{l}}\right)^{\eta} \quad a_{\lg i}=c_{\lg i}\left(\frac{w_{l}}{w_{h}}\right)^{\eta} \text { where } c_{f g i} \text { are constants }
$$

Constants, $c_{f g i}$ are chosen such that intermediate good production in each industry is relatively low-skill intensive, and production in industry 1 is relatively high-skill intensive:

$$
k_{x i}=\frac{a_{h x i}}{a_{l x i}}>k_{y i}=\frac{a_{h y i}}{a_{l y i}} \forall i, \text { and } k_{x 1}>k_{y 1}>k_{x 2}>k_{y 2}
$$


Full employment in both type labor markets requires:

$$
\begin{aligned}
& \sum_{i} \sum_{g} L_{h g i}=L_{h} \\
& \sum_{i} \sum_{g} L_{\lg i}=L_{l}
\end{aligned}
$$

There are two countries in the model, A and B, with the following relative factor abundance:

$$
k_{A}=\frac{L_{h}^{A}}{L_{l}^{A}} \quad k_{B}=\frac{L_{h}^{B}}{L_{l}^{B}}=k_{A}-s, 0 \leq s<k_{A}, \quad L_{h}^{A}+L_{l}^{A}=v \text { and } L_{h}^{B}+L_{l}^{B}=1
$$

where $s$ represents the degree of similarity in factor abundance between the two countries. By assumption, A is relatively high-skill abundant. $v$ represents the size of country A relative to B. Total population in B is assumed to be 1 . Thus, $L_{l}^{B}$ shows the percent of the population with low skills in country B.

Firms are profit-maximizers. In particular, in country A, the profit-maximizing prices of goods in industry $i$ is as follows:

$$
\begin{aligned}
& p_{x i}^{A}=a_{h x i}^{A} w_{h}^{A}+a_{l x i}^{A} w_{l}^{A}+p_{y i}^{A, \min } a_{y x i} \\
& p_{y i}^{A}=a_{h y i}^{A} w_{h}^{A}+a_{l y i}^{A} w_{l}^{A} \\
& p_{y i}^{A, \min }=\min \left(p_{y i}^{A}, p_{y i}^{A(B)}\right) \text { and } p_{g i}^{A(B)}=p_{g i}^{B}\left(1+t_{g i}^{A}+t b\right)
\end{aligned}
$$

where $p_{g i}^{A}$ and $p_{g i}^{A(B)}$ are the domestic price of good $g$ and the price of the imported variety in country A, respectively. $t_{g i}^{A}$ is the tariff rate that A applies to its imports of good $g$ in industry $i$. $t b$ represents the non-resource-consuming trade barriers. ${ }^{2}$ Note that, for producers, domestic and imported intermediate products are perfect substitutes: They choose the intermediate product with the lowest price, either domestic or imported.

Representative consumers in each country have identical nested Cobb-Douglas/CES preferences. In particular, for consumers in country A, the utility at tariff rate $t$ is as follows:

\footnotetext{
2 By non-resource consuming trade barriers, I refer to cultural differences (Dziembowska 2000), informational barriers (Bureau 1998), exchange and capital controls (Tamirisa 1998), preferential distribution networks (Scherer 1997) and border effects (Helliwell 1997). In most contexts, such barriers would not be much interesting, since they are same as tariffs. In this problem, a floor on liberalization resulting from these barriers holds some interest.
} 


$$
U_{t}^{A}=\sum_{i} \beta_{i}\left\{\alpha \ln \left(\left(C_{x i}^{A}\right)^{\Theta}+\left(C_{x i}^{A(B)}\right)^{\Theta}\right)^{\frac{1}{\Theta}}+(1-\alpha) \ln \left(\left(C_{y i}^{A}\right)^{\Theta}+\left(C_{y i}^{A(B)}\right)^{\Theta}\right)^{\frac{1}{\Theta}}\right\}
$$

where $C_{g i}^{A} g \in\{x, y\}, i \in\{1,2\}$ is consumption of good $g$ in industry $i$ produced in A. $C_{g i}^{A(B)}$ is country A's consumption of the variety produced in B. $\sum_{i} \beta_{i}=1$.

Note first that the above utility function implies that the share of expenditures on industry $i$ is $\beta_{i}$, whereas $\alpha$ is the share of expenditures on domestic and imported varieties of good $x$ in the budget allocated to an industry. Note further that consumers consider both countries' products as imperfect substitutes: Consumers, unlike producers, are conscious of the country of origin of the products they consume, and they treat imports as differentiated varieties as in Armington (1969).

Solving the consumers' problem, share of expenditures on a domestic good $g$ in industry $i$, $s_{g i}^{A}$, and on the imported variety, $s_{g i}^{A(B)}$, from the budget allocated to that product in country A are:

$$
s_{g i}^{A}=\frac{\left(\frac{p_{g i}^{A}}{p_{g i}^{A(B)}}\right)^{\frac{\Theta}{\Theta-1}}}{1+\left(\frac{p_{g i}^{A}}{p_{g i}^{A(B)}}\right)^{\frac{\Theta}{\Theta-1}}} s_{g i}^{A(B)}=\frac{1}{1+\left(\frac{p_{g i}^{A}}{p_{g i}^{A(B)}}\right)^{\frac{\Theta}{\Theta-1}}}
$$

Because of the way preferences are formulated, countries import and export each product at the same time for consumption purposes. This way, the model allows for horizontal IIT. But for production purposes, only the cheapest-producer country of an intermediate good exports it -if the tariff rates are low enough to allow trade, among other factors. Thus, the inclusion of intermediate goods to the model allows vertical IIT at low tariff rates. Since the factor abundance is different for each country, inter-industry trade also exists.

The amount of exports, $X_{g i}^{A}$, and imports, $M_{g i}^{A}$, of each good $g$ in industry $i$ will be as follows for country A: 


$$
\begin{aligned}
& X_{x i}^{A}=Q_{x i}^{A}-C_{x i}^{A} \\
& X_{y i}^{A}=Q_{y i}^{A}-C_{y i}^{A}-\left(1-z_{i}^{A}\right) a_{y x i} Q_{x i}^{A} \\
& M_{x i}^{A}=C_{x i}^{A(B)} \\
& M_{y i}^{A}=C_{y i}^{A(B)}+z_{i}^{A} a_{y x i} Q_{x i}^{A}
\end{aligned}
$$

where $z_{i}^{A}$ is 1 if country A imports the intermediate product in industry $i$. That is:

$$
\mathrm{z}_{i}^{A}=\left\{\begin{array}{ccc}
1 & \text { if } & p_{y i}^{B}\left(1+t_{y i}^{A}+t b\right)<p_{y i}^{A} \\
0 . .1 & p_{y i}^{B}\left(1+t_{y i}^{A}+t b\right)=p_{y i}^{A} \\
0 & \text { otherwise }
\end{array}\right\} \text { and } z_{i}^{A}+z_{i}^{B} \leq 1
$$

Income in each country is:

$$
\begin{aligned}
& Y^{A}=w_{h}^{A} L_{h}^{A}+w_{l}^{A} L_{l}^{A}+t_{x 1}^{A} P_{x 1}^{B} M_{x 1}^{A}+t_{y 1}^{A} P_{y 1}^{B} M_{y 1}^{A}+t_{x 2}^{A} P_{x 2}^{B} M_{x 2}^{A}+t_{y 2}^{A} P_{y 2}^{B} M_{y 2}^{A} \\
& Y^{B}=w_{h}^{B} L_{h}^{B}+w_{l}^{B} L_{l}^{B}+t_{x 1}^{B} P_{x 1}^{A} M_{x 1}^{B}+t_{y 1}^{B} P_{y 1}^{A} M_{y 1}^{B}+t_{x 2}^{B} P_{x 2}^{A} M_{x 2}^{B}+t_{y 2}^{B} P_{y 2}^{A} M_{y 2}^{B}
\end{aligned}
$$

where the first two terms denote labor incomes and the last four terms represent tariff revenues from imports.

Using the following goods-market-equilibrium conditions, the model now can be solved:

$$
\begin{aligned}
& X_{x i}^{A}=M_{x i}^{B} \forall i \\
& X_{y i}^{A}=M_{y i}^{B} \forall i \\
& M_{x i}^{A}=X_{x i}^{B} \quad \forall i \\
& M_{y i}^{A}=X_{y i}^{B} \quad \forall i
\end{aligned}
$$

Since the focus of the model is the adjustment of labor and welfare gains implied by different types of trade, there is a need to decompose the total trade into its types. This is done as follows: The intra-industry trade, IIT, is the amount of matched trade in each industry. This makes interindustry trade, INT, the difference between total trade, TT, and IIT. Horizontal intra-industry trade, hIIT, is the amount of matched trade in each good. Thus, the amount of vertical intraindustry trade, $v I I T$, is the difference between IIT and horizontal IIT. Detailed expressions are given below: 


$$
\begin{aligned}
T T= & X_{x 1}^{A} P_{x 1}^{A}+M_{x 1}^{A} P_{x 1}^{B}+X_{y 1}^{A} P_{y 1}^{A}+M_{y 1}^{A} P_{y 1}^{B}+ \\
& +X_{x 2}^{A} P_{x 2}^{A}+M_{x 2}^{A} P_{x 2}^{B}+X_{y 2}^{A} P_{y 2}^{A}+M_{y 2}^{A} P_{x 2}^{B} \\
I I T= & X_{x 1}^{A} P_{x 1}^{A}+M_{x 1}^{A} P_{x 1}^{B}+X_{y 1}^{A} P_{y 1}^{A}+M_{y 1}^{A} P_{y 1}^{B}- \\
& -\left|X_{x 1}^{A} P_{x 1}^{A}+X_{y 1}^{A} P_{y 1}^{A}-M_{x 1}^{A} P_{x 1}^{B}-M_{y 1}^{A} P_{y 1}^{B}\right|+ \\
& +X_{x 2}^{A} P_{x 2}^{A}+M_{x 2}^{A} P_{x 2}^{B}+X_{y 2}^{A} P_{y 2}^{A}+M_{y 2}^{A} P_{y 2}^{B}- \\
& -\left|X_{x 2}^{A} P_{x 2}^{A}+X_{y 2}^{A} P_{y 2}^{A}-M_{x 2}^{A} P_{x 2}^{B}-M_{y 2}^{A} P_{y 2}^{B}\right| \\
I N T= & T T-I I T \\
h I I T= & X_{x 1}^{A} P_{x 1}^{A}+M_{x 1}^{A} P_{x 1}^{B}-\left|X_{x 1}^{A} P_{x 1}^{A}-M_{x 1}^{A} P_{x 1}^{B}\right|+ \\
& +X_{y 1}^{A} P_{y 1}^{A}+M_{y 1}^{A} P_{y 1}^{B}-\left|X_{y 1}^{A} P_{y 1}^{A}-M_{y 1}^{A} P_{y 1}^{B}\right|+ \\
& +X_{x 2}^{A} P_{x 2}^{A}+M_{x 2}^{A} P_{x 2}^{B}-\left|X_{x 2}^{A} P_{x 2}^{A}-M_{x 2}^{A} P_{x 2}^{B}\right|+ \\
& +X_{y 2}^{A} P_{y 2}^{A}+M_{y 2}^{A} P_{y 2}^{B}-\left|X_{y 2}^{A} P_{y 2}^{A}-M_{y 2}^{A} P_{y 2}^{B}\right| \\
v I I T= & I I T-h I I T
\end{aligned}
$$

Labor is mobile across industries and firms within an industry. As they move due to liberalization, their relocation is costly due to moving costs, training costs, and other costs known as adjustment costs. In this paper, aggregate amount of labor relocations within an industry or across industries is used to proxy the adjustment costs. ${ }^{3}$ Size of labor adjustment relative to total labor force associated with a decrease in the tariff rates from $t_{1}$ to $t_{2}$ is measured as follows:

$$
\begin{gathered}
\Delta L_{t_{1}}^{t_{2}}=-\sum_{i}\left(\sum_{g} \Delta L_{h g i}+\sum_{g} \Delta L_{\lg i}\right) \\
\Delta L_{h g i}<0 \quad \Delta L_{\lg i}<0
\end{gathered}
$$

where $\Delta L_{f g i}$ is the decrease in the amount of factor $f$ employed in the production of good $g$ in industry $i$ resulting from the decrease in tariff rates. When labor is relocated, a decrease in the employment of a firm implies an increase in the employment of another. This is the reason why the summation is carried out only over the goods (firms) where there are decreases in employment. This is done separately for each type of labor.

\footnotetext{
${ }^{3}$ I recognize that the elapsed time until finding a new job will vary from one type of labor to another, and so will the resource costs of moving. For simplification, I assume that the adjustment costs associated with relocation of both high- and low-skill labor are the same. Note also that the adjustment costs here are not modeled into the behavior of the labor to be displaced. Labor in certain good's production in certain industries will be laid off due to adjustments, but that is not a decision made by labor. They do not decide whether to move or not based on the size of the costs involved in relocation.
} 
Cline et al. (1978), Baldwin, Mutti and Richardson (1980), de Melo and Tarr (1988) use a similar method: They calculate the amount of labor that moves between industries between two long-run equilibria and then calculate what adjustment costs are implied by this change. However, they take into account only inter-industry factor allocations, and ignore the adjustment costs of intra-industry labor movements resulting from vertical IIT changes.

\section{Results of the model}

In this section, using the above model, I analyze the effects of different trade liberalization policies on the types of trade, the adjustment of labor and the welfare gains. I consider countryand industry-asymmetric liberalizations. I compare their outcomes to that of symmetric liberalization, where all tariff rates for both countries are lowered at the same rate. Apart from asymmetries, I also analyze the effects of similarity in terms of factor endowments, and the relative size of countries, as well as those of non-resource-consuming trade barriers.

Given the complexity of the equations in this model, it is not practical to get closed form solution that shows the relations I am interested in, i.e. the relations between different types of trade and the amount of labor adjustment and welfare gains. Therefore, the results come from simulations. The plots presented in this section assume certain values for the constants of the model. Robustness of the results is checked by varying the constants assumed. ${ }^{4}$ Accordingly, $a_{y x i}$ is 1 in both industries. This implies that the production of a unit of final good requires one unit of the intermediate good in the same industry. The factor demand elasticity ${ }^{5}, \eta$, is $-1 . \beta_{i}$ is $1 / 2$, which implies that the share of consumer expenditures on each industry is $50 \%$. $\alpha$ is $3 / 4$ such that a

\footnotetext{
${ }^{4}$ The following values are tried in computations and in checking the robustness of the model's results: $a_{y x \mathrm{i}}=\{0.5, \mathbf{1}, 2\} ; \eta=\{-0.8, \mathbf{- 1},-1.2\} ; \beta_{i}=\{0.25, \mathbf{0 . 5 0}, 0.75\} ; \alpha=\{0.25,0.50, \mathbf{0 . 7 5}\} ; L_{l}^{A}=\{0.1, \mathbf{0 . 2}, 0.25\}$; $v=\{0.5, \mathbf{1}, 2\} \quad s=\{1,2.5,3,3.25,3.75\} ;\left[c_{h x l}, c_{h y l}, c_{h x 2}, c_{h y 2}\right]=\{[\mathbf{3 . 8}, \mathbf{3 . 6}, \mathbf{1 . 4}, \mathbf{1 . 2}],[8,6,4,2]$, $[0.8,0.7,0.3,0.2],[8,6,0.4,0.2]\} ; \Theta=\{1 / 2, \mathbf{5 / 6}\}$. The results reported assume the parameters printed in bold.

${ }^{5}$ Slaughter (1997) analyzes the effects of trade liberalization on labor demand elasticity and finds mixed results for whether trade liberalization increases elasticity. His empirical analysis finds the elasticity to be around -0.6 and -1.3 for the manufacturing sector. Therefore, presented results will assume that the elasticity does not change during liberalization and is equal to -1 .
} 
bigger share of the expenditures within an industry goes towards purchases of final goods, compared those on intermediate goods. Furthermore, $\Theta$ is $5 / 6$, implying that the elasticity of substitution is $6{ }^{6}$ The constants, $c_{f g i}$, are chosen such that the factor intensity assumptions in (4) are met. $^{7} L_{l}^{A}$ is 0.2 such that $20 \%$ of the population in country A has low skills. This implies that the relative factor abundance in $\mathrm{A}, k_{A}$, is 4 . Degree of similarity, $s$, is initially 2.5 , implying that the relative factor abundance in $\mathrm{B}$ is 1.5 ; that is, $40 \%$ of the population in country $\mathrm{B}$ has low skills. The relative size of country A, $v$, is 1 , which implies the same size for the population of both countries. Non-resource-consuming trade barriers are initially assumed to be zero.

Liberalization policies are analyzed as tariff rates are lowered from $50 \%$ down to $0 \%$, in decrements of one percentage point. In each step, first, certain wage rates are assumed for highand low-skill labor in both countries. Using these wage rates, first the unit factor requirements, and then the prices of goods in every industry for both countries are computed. Next, with the help of Equation (11), I find out whether any country will be importing an intermediate product for production purposes. Later, I check if the goods-market-equilibrium conditions are met. Different wage rates are tried until the wage rates that satisfy the equilibrium conditions by an insignificant amount of excess, which is set at $0.1 \%$, are found ${ }^{8}$ Finally, shares of different types of trade, adjustment of labor, and welfare gains are computed.

\section{a. Symmetric liberalization}

Figure 1 shows the effects of a symmetric liberalization: Both countries are initially levying the same tariff rates on all imports; and these tariffs are lowered at the same rate. At high tariffs, there is only inter-industry and horizontal intra-industry trade. As liberalization lowers the tariffs for the imports, the share of horizontal IIT starts increasing smoothly. This is a direct result of Equation (9): Both countries, imports become relatively cheaper; and they start importing and

\footnotetext{
${ }^{6}$ Empirical literature consensus on elasticity of substitution between imported and domestic varieties is 6 . See Feenstra (1994) and Hanson (1999).

${ }_{8}^{7}\left[c_{h x 1}, c_{h y 1}, c_{h x 2}, c_{h y 2}\right]=[3.8,3.6,1.4,1.2] c_{l g i}=1 \forall g$, and $\forall i$.

8 This explains the wiggles in the figures showing the results. Sometimes, the markets clear with an insignificant excess supply, sometimes with an insignificant excess demand.
} 
exporting different varieties of the same product more. Later, an increase in the share of interindustry trade occurs as countries specialize in the industry that intensively uses their relatively abundant factor. This specialization does not become significant until tariff rates are low enough. To observe inter-industry trade between countries $C$ and $C^{\prime}$ in good $g$ in industry $i$, tariff rates should be low enough to satisfy the following, where $C$ is the importer of the good:

$$
\begin{aligned}
& P_{g i}^{C\left(C^{\prime}\right)}<P_{g i}^{C} \\
& P_{g i}^{C^{\prime}}\left(1+t_{g i}^{C}\right)<P_{g i}^{C}
\end{aligned}
$$

When the rates are further lowered, vertical IIT appears. As implied by Equation (11), tariff should be very low to exploit the intra-industry advantages and start importing the intermediate products for production purposes. In particular, the following is needed to have vertical IIT between countries $C$ and $C^{\prime}$ in industry $i$, where $C$ imports the intermediate good, processes it further, and exports the final good back to $C^{\prime}$ :

$$
\begin{aligned}
& P_{y i}^{C\left(C^{\prime}\right)}<P_{y i}^{C} \text { and } P_{x i}^{C^{\prime}(C)}<P_{x i}^{C^{\prime}} \\
& P_{y i}^{C^{\prime}}\left(1+t_{y i}^{C}\right)<P_{y i}^{C} \text { and } P_{x i}^{C}\left(1+t_{x i}^{C^{\prime}}\right)<P_{x i}^{C^{\prime}} \\
& P_{y i}^{C^{\prime}}\left(1+t_{y i}^{C}\right)<P_{y i}^{C} \text { and }\left(w_{h}^{C} a_{h x i}^{C}+w_{l}^{C} a_{l x i}^{C}+P_{y i}^{C^{\prime}}\left(1+t_{y i}^{C}\right) a_{y x i}^{C}\right)\left(1+t_{x i}^{C^{\prime}}\right)<P_{x i}^{C^{\prime}}
\end{aligned}
$$

Figure $1 \mathrm{~b}$ shows labor adjustments and welfare gains for both countries throughout the liberalization. Here, $\Delta L_{50}^{t} / L$ shows the share of aggregate labor relocations in both countries to total labor force in both, as tariff rates are lowered from $50 \%$ to a particular rate $t . \Delta U_{0.5}^{t} / U_{0.5}$ shows the percentage change in utility in both countries form the utility at the beginning of liberalization, $U_{50}$. Individual labor adjustments and welfare gains for each country are not plotted, but will be given in numbers.

Initially, very small adjustment of labor is observed associated with the increase in horizontal IIT. Then, adjustment of labor increases faster during the period of increases in inter-industry trade. At low tariffs, further labor relocations occur, simultaneously with the vertical IIT. This finding supports the proposition that vertical IIT is costlier than horizontal IIT. The amount of labor relocations due to vertical IIT, however, is not as high as that associated with inter-industry 
trade. At the end of the liberalization, $29 \%$ of labor force in both countries is relocated. The adjustment in the more skilled country A is about $22 \%$ of its labor force, and it is around $37 \%$ of labor force in country B.

Welfare follows similar changes. Most of the benefits of integration are observed towards the end of liberalization, where there is an increase in specialization, as seen by the increase in interindustry trade, and increase in outsourcing, as observed by the increase in vertical IIT. Overall gains in welfare are about $14 \%$. The high-skill abundant country A experiences around $8 \%$ increase in its welfare, whereas B experiences more than $21 \%$ increase. Interestingly, low-skill country experiences higher adjustment costs, but this is associated with larger gains in welfare.

\section{b. Industry-asymmetric liberalization}

Figure 2 shows the effects of having sensitive industries in a liberalization policy. In this case, each country liberalizes only the industry in which it has comparative advantage. Consequently, high-skill abundant country A has comparative advantage in industry 1 , and B has an advantage in industry 2 . The tariff rates in these industries are assumed to be the same in both countries, and are lowered at the same rate, while sensitive sectors of each country are kept protected at tariff rates of $50 \%$.

There are three main differences between this and the symmetric case: First, no vertical IIT is observed, not even at low tariff rates. Obviously, keeping the sectors that the partner country has advantage out of liberalization does not allow for intra-industry specialization through vertical IIT. Second, the adjustment of labor is higher than that in symmetric liberalization, about $78 \%$ versus $29 \%$ of total labor force. In particular, labor relocations amount to $84 \%$ of the labor force

in country A, and $66 \%$ of the labor force in B. Higher labor adjustments can be explained by the fact that at low tariff rates the increase is just inter-industry, rather than a combination of interindustry and vertical IIT as in the symmetric case. This observation provide further evidence that even if vertical IIT changes causes some labor relocations, they are not as high as the one caused by inter-industry trade changes. Lastly, welfare gains are smaller, namely about $12 \%$ increase. 
Lower gain is quite intuitive since this liberalization does not allow much room for fully exploiting partner's advantage through specialization. High-skill country A does not experience a significant increase in its welfare, whereas B experiences an increase by about $19 \%$. It is interesting to see that, even if low-skill country B has lower adjustment than A, B is the country that collects most of the benefits of integration.

\section{c. Country-asymmetric liberalization}

This case is intended to illustrate what happens when one partner liberalizes its trade faster than the other. In practice, the more developed partner typically liberalizes faster. In the model, country A's population is relatively more skilled, i.e. more developed by assumption. Therefore, it is assumed that A lowers its tariff barriers at the same rate for all industries and goods. B's tariff rates are kept at 50\%. Figure 3 shows the effects of this country asymmetry.

As tariff rates are lowered, an increase in the share of horizontal IIT is experienced due to lower relative prices of imported varieties. However, in this case, neither a sharp increase in the share of inter-industry trade at low tariff rates, nor any vertical IIT is observed. Apparently, with only one country liberalizing its trade, there is not much room for inter-industry or intra-industry specialization. Since the changes in inter-industry trade are small, there are small labor adjustments, only about $4 \%$ of total labor force. The adjustment in country A amounts to around $5 \%$ of its labor force, whereas they are about $4 \%$ in $\mathrm{B}$. This result is also intuitive: The country that liberalizes its market bears more adjustment. Without much specialization, the welfare gains are small, about $11 \%$, compared to $14 \%$ in symmetric liberalization. In particular, country A's welfare gains are at around $4 \%$, versus $16 \%$ for country B. Once again, the gains in low-skill country B are higher. Obviously, the more advanced country does not have much to gain from liberalization with a low-skill abundant country.

\section{d. Effect of similarity of countries' factor abundance}

The effects of similarity are explored in Figure 4. Different factor abundance degrees, $s=k_{A^{-}}$ $k_{B}=1$, and 3 are analyzed, while the portion of low-skill labor in country A is kept at $20 \%$. Then, 
the corresponding part of B's population with low skill is $25 \%$, and $50 \%$, respectively. The former case is used to analyze the effects of liberalization between two fairly similar countries, and the latter for those of significantly different ones. Tariff rates for all goods in both countries are lowered at the same rate as in the case of symmetric liberalization.

In both cases, the same trend throughout the liberalization is observed: First, the share of horizontal IIT increases, then that of the inter-industry trade, and at very low tariff rates, vertical IIT emerges. In the first case, however, countries are very similar, and therefore not much interindustry trade develops. An increase in its share is observed only at very low tariff rates. Consistent with this observation, labor adjustment is somewhat smaller. In country A, it amounts to about $35 \%$ of labor force, whereas it is around $22 \%$ in B. Furthermore, since there is not much room to exploit each other's comparative advantage due to high similarity, welfare gains are also relatively low. In particular, country A gains $6 \%$, versus $19 \%$ gain in $\mathrm{B}$. In the second case, countries are very different from each other; more inter-industry specialization, and vertical intraindustry specialization is observed. There are higher welfare gains, through inter- and vertical intra-industry specialization. Country A gains about 13\% increase in its welfare, whereas B gains around $24 \%$. One more time, low-skill country gains more. There is a lot of labor relocation when countries are different in terms of factor abundance. In particular, country A experiences adjustments of labor amounting to about $67 \%$ of its labor force, and in B around $106 \%$.

\section{e. Effect of relative population size}

The analysis so far assumes that the two countries have the same population size. In this segment, the effects of changing the relative size of countries are analyzed. Country A's population is first assumed to be half of the population of $\mathrm{B}$, and then twice that of $\mathrm{B}$. A symmetric liberalization is assumed. The shares of different types of trade during the path of a symmetric liberalization are shown in Figures $5 \mathrm{a}$ and $5 \mathrm{c}$ for each case. First, some similarities are noted: At first, the share of horizontal IIT increases, then the share of inter-industry trade. Finally at low tariff rates, vertical IIT starts. 
Combined labor adjustments and welfare gains throughout the liberalization are plotted in Figures $5 \mathrm{~b}$ and $5 \mathrm{~d}$, respectively for each case. When the skill abundant country A's population is half that of low-skill country B, welfare gains in A are about $38 \%$, and approximately $16 \%$ in $\mathrm{B}$. However, when country A is twice as populated as B, the welfare gains in A fall down to $4 \%$, the gains for B increase to $43 \%$. The model suggests that small countries benefit more from trade liberalization. When country A is the smaller of the two, adjustment of labor are about $67 \%$ of its labor force, and that in country B is about $53 \%$ of its labor force. However, when country A is twice as populated as $\mathrm{B}$, the labor adjustments in A fall down to $28 \%$ of its labor force, the adjustments for B fall to $48 \%$ of labor force. Intuitively, when the bigger country is skill abundant, liberalization does not result in much labor relocations. Furthermore, more labor adjustments are born by the low-skill country, but it also captures higher welfare gains. When the low-skill country is bigger adjustment for both are higher, but so are the welfare gains.

\section{f. Non-resource consuming trade barriers}

These trade barriers work as ad-valorem tariffs that do not go down to zero like a floor on liberalization. That is, even if the tariff rates are zero, these barriers might prevent the changes observed at low tariff rates. For example, in the case of symmetric liberalization, the increase in inter-industry trade or the vertical IIT at low tariff rates may not be observed. This partly explains why the share of vertical IIT is higher for neighboring countries, which presumably experience lower trade barriers. Furthermore, previous analysis showed that most of the adjustment of labor and welfare gains occurs at low tariff rates. If the size of these trade barriers is large enough, there may not be much welfare gains associated with integration, neither will there be much structural adjustment.

When robustness of the results is checked, the general patterns of changes are preserved. However, using different constants slightly alters the magnitude and timing these changes. ${ }^{9}$ 


\section{Conclusion}

In this paper, I first argue that vertical IIT should be treated separate from horizontal IIT. Unlike horizontal IIT, different skills involved in goods exchanged under vertical IIT. Therefore it should imply adjustment of labor and welfare gains of different magnitudes. Later, using a model that allows for both vertical and horizontal IIT as well as inter-industry trade, I analyze the effects of symmetric, and country- and industry-asymmetric liberalization policies on the shares of different types of trade, the associated adjustment of labor, and the welfare gains. I also explore the effects of factor-abundance similarity, different population size, and non-resourceconsuming trade barriers. Model's results are suggestive, but interesting.

The EA signed between the EU and the CEEC have both country- and industry-asymmetric features. The partners involved are different in size, but similar in terms of skilled labor endowments. ${ }^{10}$ According to the results of the model, this liberalization policy adopted by the EA merely increases the share of horizontal intra-industry trade, primarily because of countryasymmetry. Not much increase in vertical IIT is predicted because of its industry-asymmetric feature. These asymmetries combined with high similarity in factor abundance do not yield much inter- or intra-industry specialization. Not much specialization also implies small adjustment, as well as small welfare gains, as suggested by the results of liberalization between two similar countries. Being the smaller partner CEEC captures most of the benefits of integration. Consequently, the welfare gains in the EU are estimated to be small. Higher welfare gains, however, implies higher costs for CEEC.

Other empirical analyses on CEEC-EU trade find some increase in inter-industry trade with substantial increase horizontal IIT, but no significant increase in vertical IIT. This observation is

\footnotetext{
${ }^{9}$ The results of the robustness analysis, and the associated graphs are available from the author upon request.

${ }^{10}$ The EA opened the EU market of about 350 million people compared to total of 100 million people in the CEEC. In terms of relative factor abundance, CEEC could be as skill intensive as the EU, considering the importance given to education for many years under central planning.
} 
supported by the findings of Daviddi (1992), Cadot and de Melo (1995), and de Melo and Tarr (1988). These results are in accordance with the model's outcome.

\section{Acknowledgements}

I have benefited a great deal from the comments and suggestions by Alan Deardorff, Robert

Stern, Gordon Hanson, Jan Svejnar, Katherine Terrell and other seminar participants at the University of Michigan - Ann Arbor. 


\section{References}

Antweiler, W., and D. Trefler (1997) Increasing Returns and All That: A View from Trade. University of British Columbia and University of Toronto.

Armington, P. (1969) A Theory of Demand for Products Distinguished by Place of Origin. IMF Staff Papers 16(1): 159-78.

Baldwin, R., J. Mutti, and D. Richardson (1980) Welfare Effects on the United States of a Significant Multilateral Tariff Reduction. Journal of International Economics 10: 405-23.

Bhagwati, J., and V. Dehejia (1994) Freer Trade and Wages of the Unskilled -Is Marx Striking Again? In Jagdish Bhagwati and Marvin Kosters (eds.), Trade and Wages: Leveling Wages Down? The American Enterprise Institute Press, Washington, D.C: 36-75.

Buhr, B. (1997) Dynamic Adjustment in Vertically Linked Markets: The Case of the U.S. Beef Industry. American Journal of Agricultural Economics 79(1): 126-38.

Bureau, J. (1998) Non-tariff Trade Barriers and Consumer's Information: The Case of the EU-US Trade Dispute over Beef. European Review of Agricultural Economics 25(4): 437-62.

Cadot, O. and J. de Melo (1995) France and the CEECs: Adjusting to Another Enlargement, in R. Faini and R. Portes (eds.), European Union Trade with Eastern Europe: Adjustment and Opportunities. London, Center for Economic Policy Research: 86-122.

Cline, W. et al. (1978) Trade Negotiations in Tokyo Round: A Quantitative Assessment. Brookings Institution, Washington D.C.

Daviddi, R. (1992) From the CMEA to the Europe Agreements: Trade and Aid in the Relations between the European Community and Eastern Europe. Economic Systems 16: 269-94.

de Melo, J., and D. Tarr (1988) Welfare Costs of U.S. Quotas in Textiles, Steel and Autos. Paper presented at a General Equilibrium Trade Policy Modeling Conference held on March 24, 1988, University of Western Ontario, London, Canada.

Dziembowska, J. (2000) Cultural Activities as a Location Factor in European Competition between Regions: Concepts and Some Evidence. Annals of Regional Science 34(1): 1-12.

Feenstra, R., and G. Hanson (1995) Foreign Investment, Outsourcing and Relative Wages. NBER Working Paper 5121.

Feenstra, R. (1994) New Product Varieties and the Measurement of International Prices. American Economic Review 84: 157-77.

Findlay, C. et al. (1992) Vertical Integration in International Trade: Exports of Primary Produce to Japan. In P. Sheard (ed.), International Adjustment and the Japanese Firm, St. Leonards: 160-76.

Hanson, G. (1999) Market Potential, Increasing Returns, and Geographic Concentration, mimeo. University of Michigan and NBER.

Helliwell, J. (1997) National Borders, Trade and Migration. NBER Working Paper 6027. 
Kaminski, B. (1995) The Significance of Europe Agreements for Central European Industrial Exports. Russian and East European Finance and Trade 19: 9-47.

Krugman, P. (1996) Does Third World Growth Hurt First World Prosperity? Harvard Business Review 72: 113-21.

Leamer, E. (1996) In Search of Stolper-Samuelson Effects on U.S. Wages. NBER Working Paper 5427.

Messerlin, P. (1993) The Trade Relations of Central and Eastern European Countries. Mimeo.

Scherer, F. (1997) Retail Distribution Channel Barriers to International Trade. University of Cambridge, ESRC Center for Business Research Working Paper WP55.

Slaughter, M. (1997) International Trade and Labor Demand Elasticities. NBER Working Paper 6262.

Tamirisa, N. (1998) Exchange and Capital Controls as Barriers to Trade. IMF Working Paper: WP/98/81.

Winters, A. (1993) The Europe Agreements: With a Little Help from Our Friends. In M. Murshed and R. Kunibert (eds.), Trade, Transfers and Development: Problems and Prospects for the Twenty-first Century. Ashgate, Brookfield: 196-209. 
William Davidson Working Paper 568

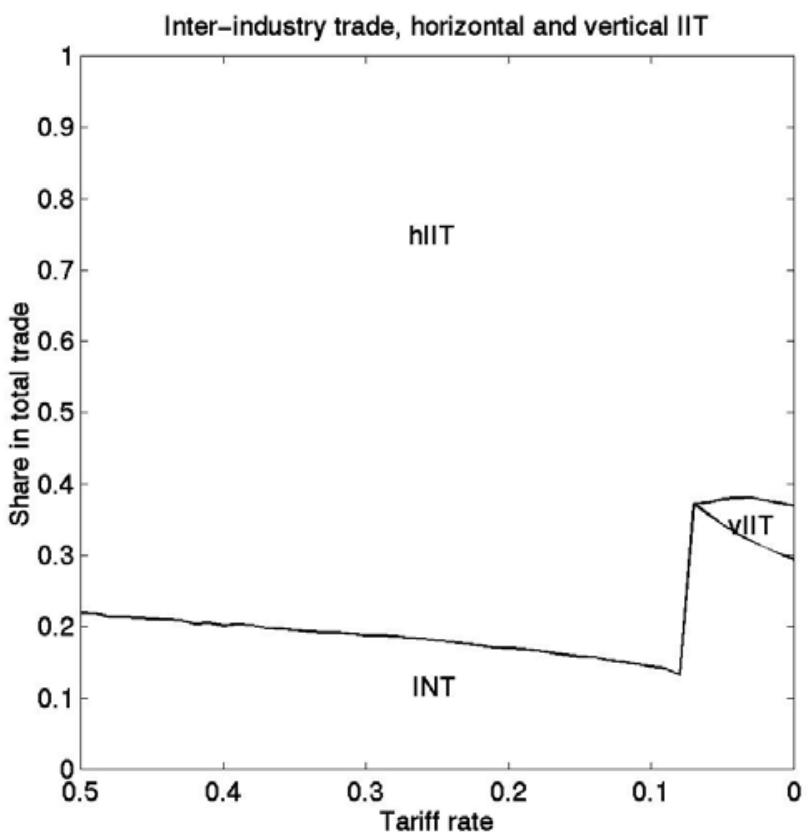

(a)

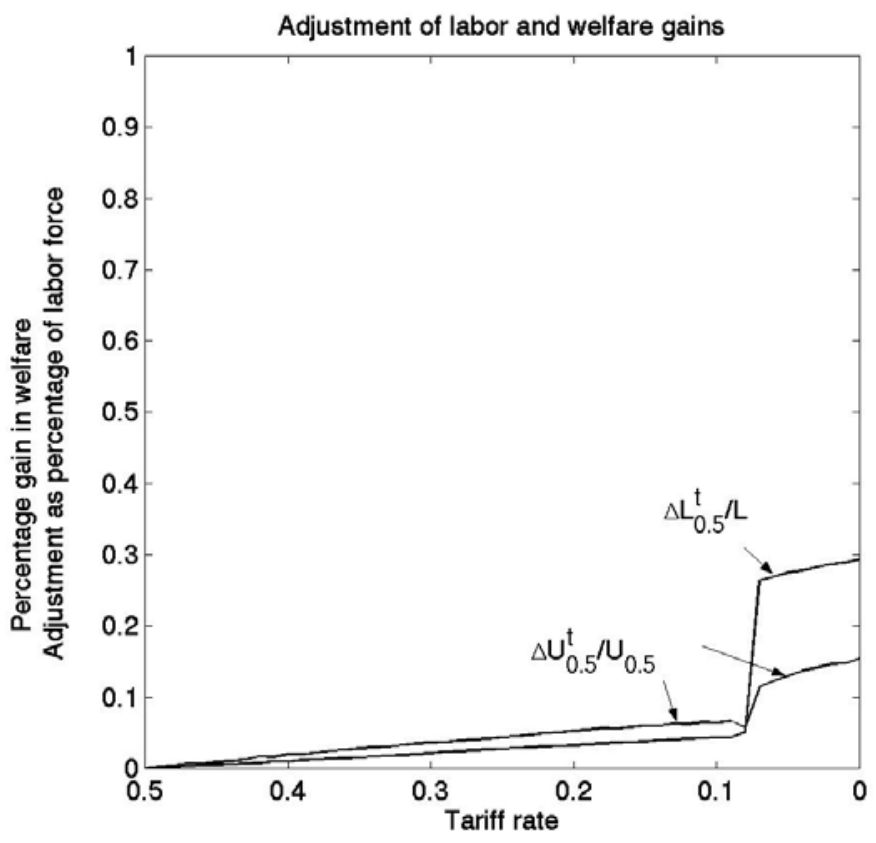

(b)

Figure 1. Symmetric trade liberalization

All tariff rates are lowered at the same rate 


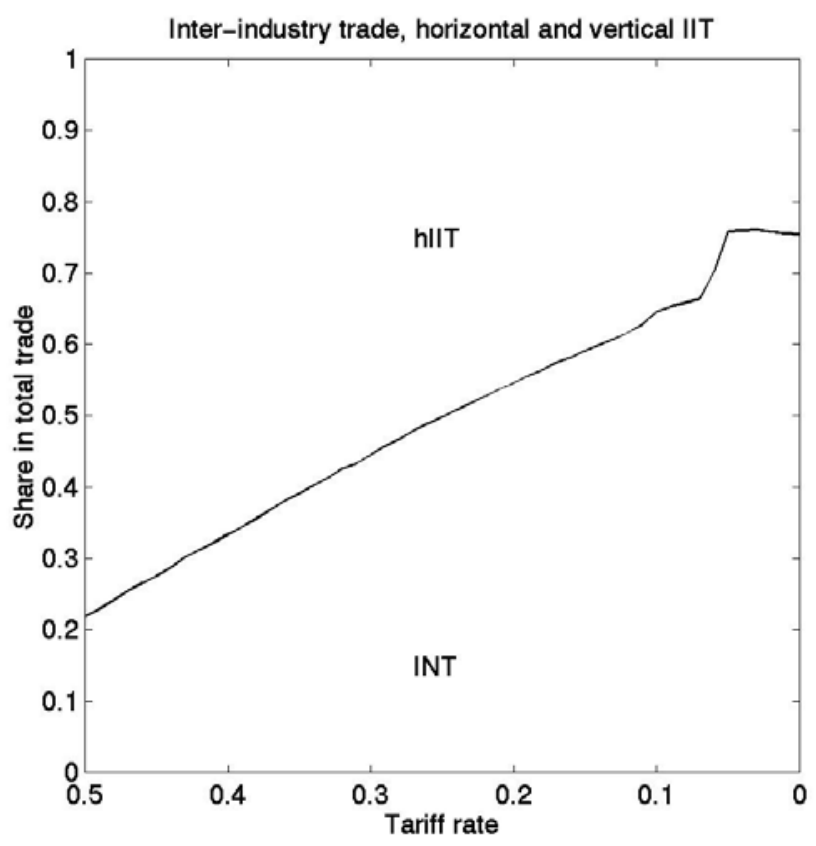

(a)

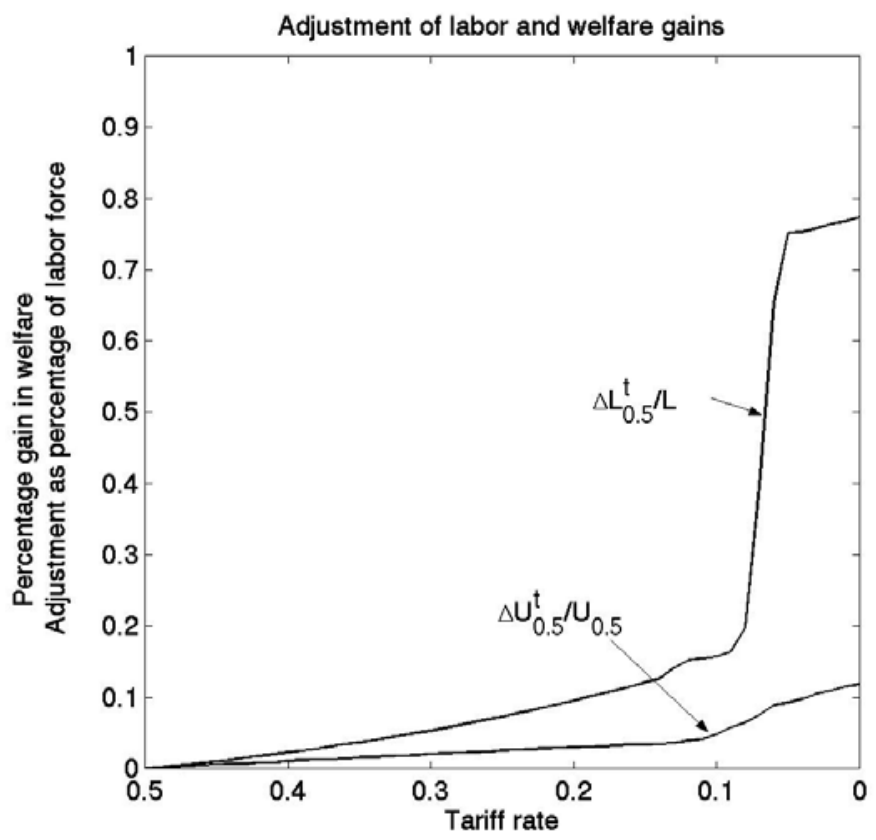

(b)

Figure 2. Industry-asymmetric liberalization

Country A protects its industry 1.

Country B protects its industry 2 .

All other tariff rates are lowered at the same rate. 
William Davidson Working Paper 568

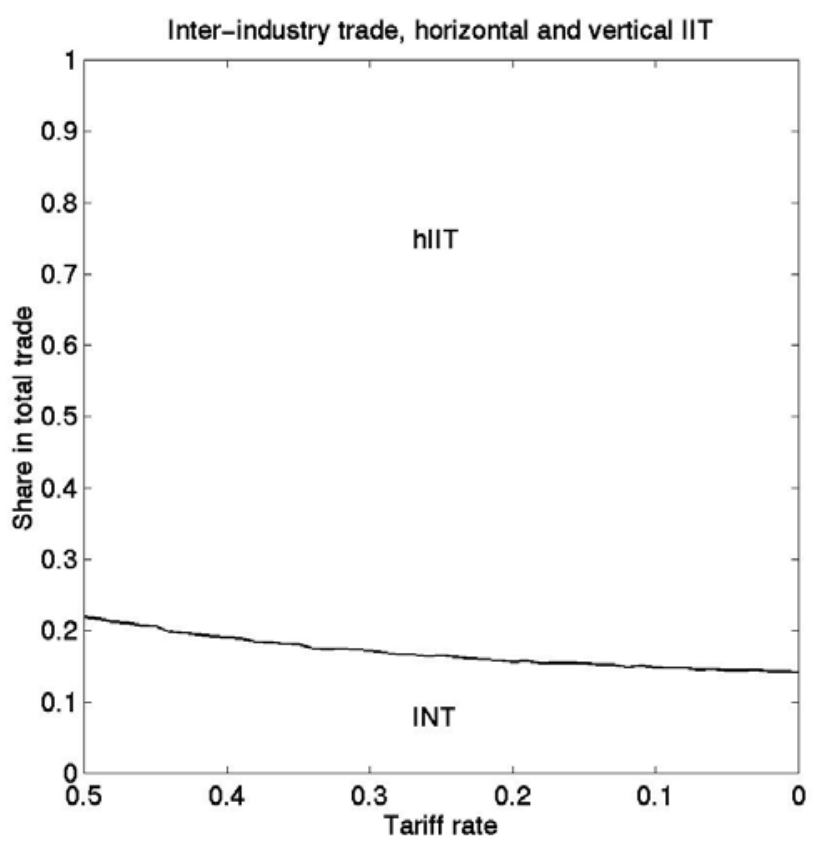

(a)

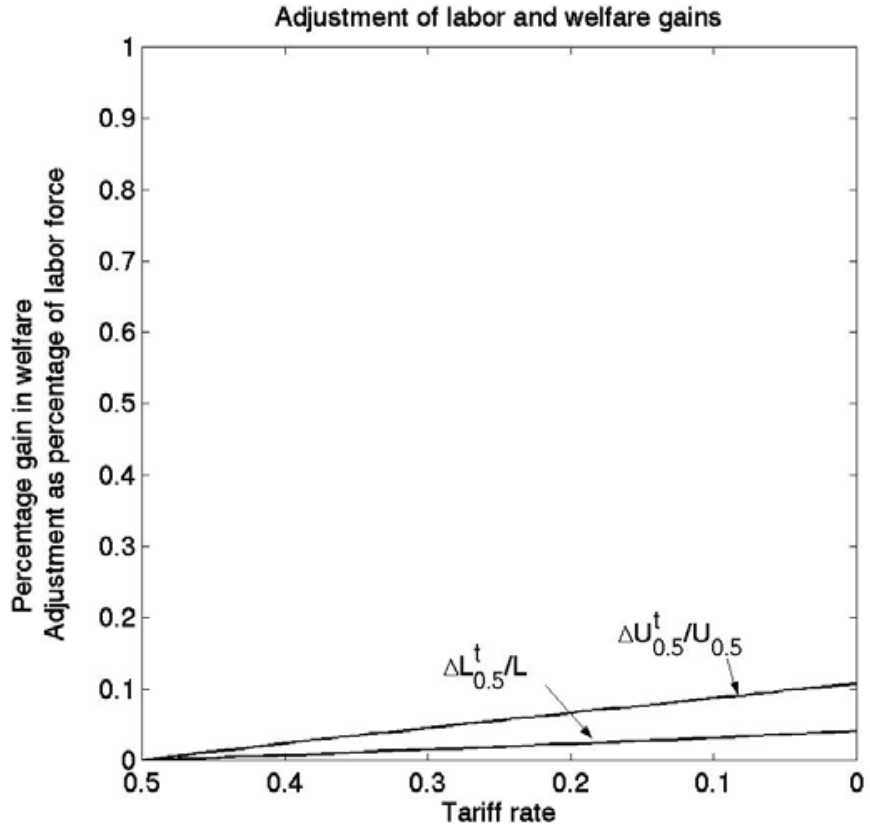

(b)

Figure 3. Country-asymmetric liberalization

Only country A liberalizes its trade at the same rate for all goods. 


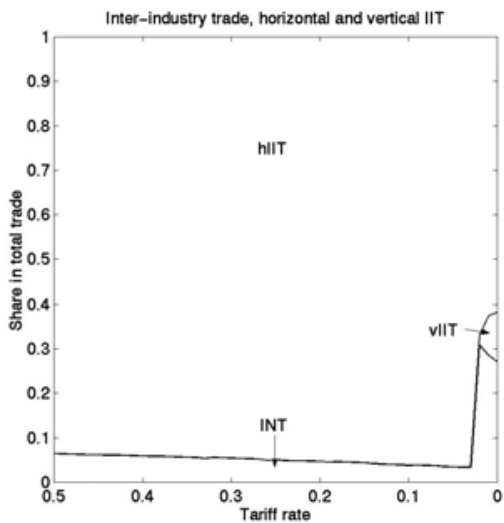

(a)

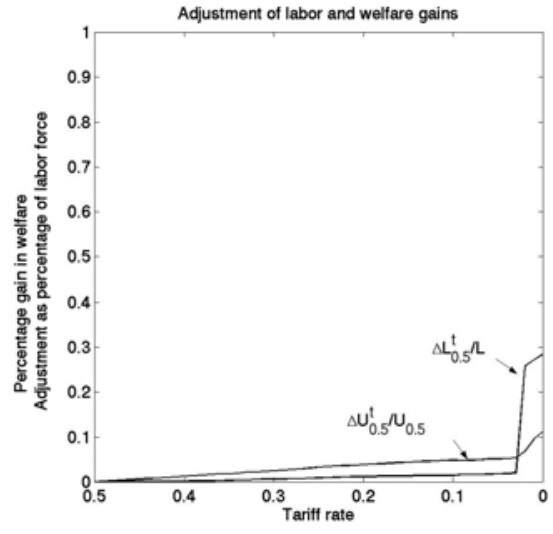

(b)

$$
L_{l}^{A}=20 \% L_{h}{ }^{A}=80 \% L_{l}{ }^{B}=25 \% L_{h}{ }^{B}=75 \%
$$

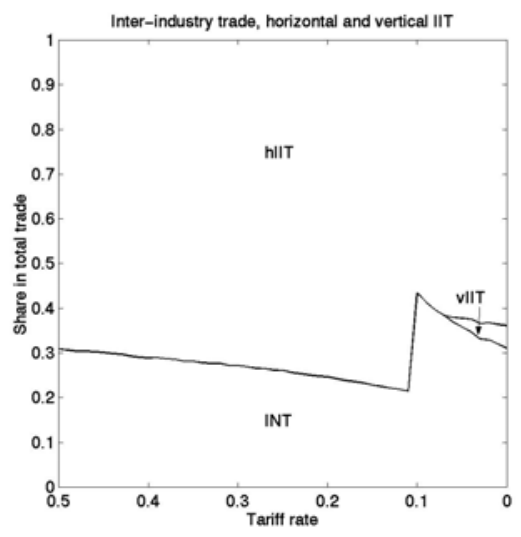

(c)

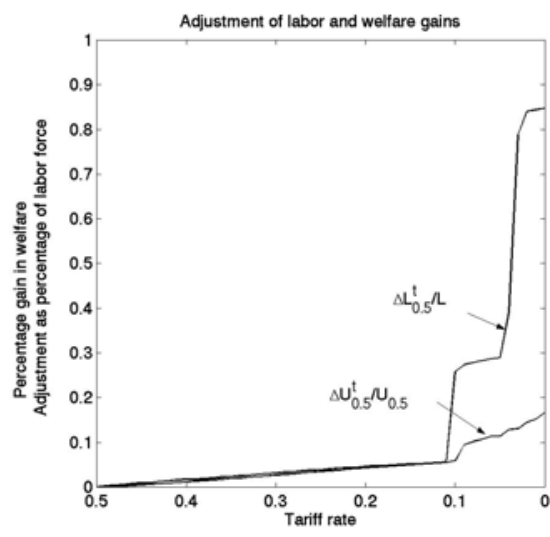

(d)

$$
\begin{gathered}
s=3 \\
L_{l}^{A}=20 \% L_{h}^{A}=80 \% L_{l}^{B}=50 \% L_{h}{ }^{B}=50 \%
\end{gathered}
$$

Figure 4. Similarity in factor abundance

All tariff rates are lowered at the same rate in both countries. 


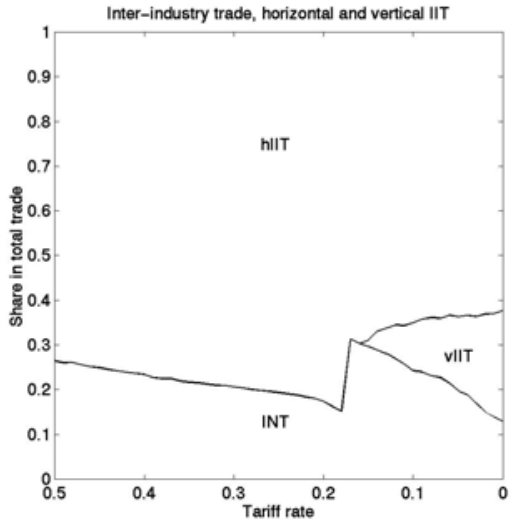

(a)

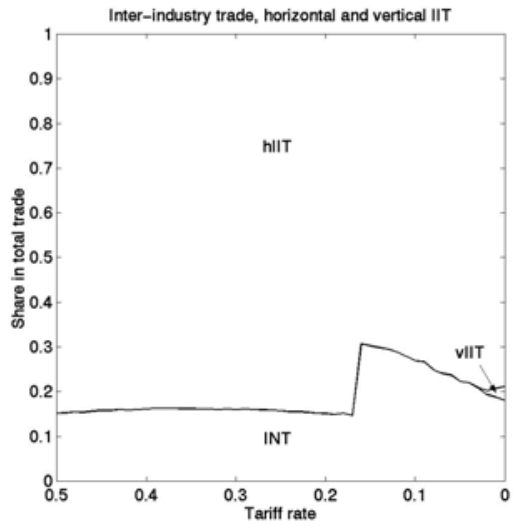

(c)

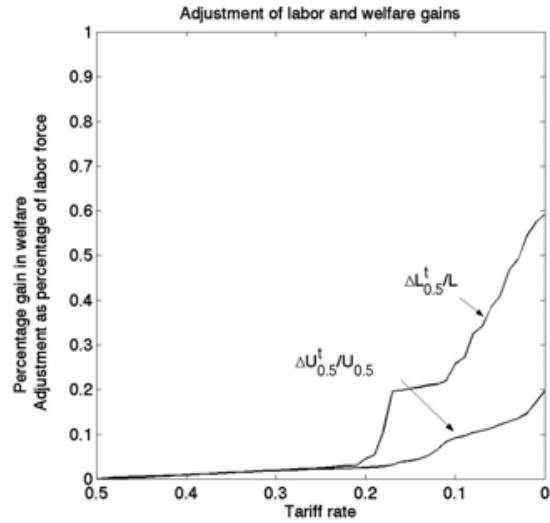

(b)

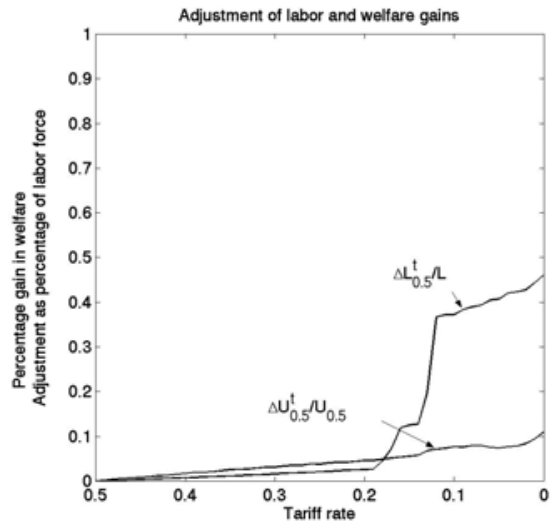

(d)

$$
\begin{aligned}
v & =2 \\
L^{A} & =2 L^{B}
\end{aligned}
$$

Figure 5. Difference in population size

All tariff rates are lowered at the same rate in both countries. $L^{A}$ and $L^{B}$ are the total population sizes in A and $\mathrm{B}$, respectively. 


\section{DAVIDSON INSTITUTE WORKING PAPER SERIES - Most Recent Papers}

The entire Working Paper Series may be downloaded free of charge at: www.wdi.bus.umich.edu

CURRENT AS OF 5/2/03

\begin{tabular}{|c|c|c|}
\hline Publication & Authors & Date \\
\hline $\begin{array}{l}\text { No. 568: On Types of Trade, Adjustment of Labor and Welfare Gains } \\
\text { During Asymmetric Liberalizations }\end{array}$ & Yener Kandogan & May 2003 \\
\hline $\begin{array}{l}\text { No. 567: Technological Progress Through Trade Liberalization in } \\
\text { Transition Countries }\end{array}$ & Yener Kandogan & May 2003 \\
\hline $\begin{array}{l}\text { No. 566: Intra-industry Trade of Transition Countries: Trends and } \\
\text { Determinants }\end{array}$ & Yener Kandogan & May 2003 \\
\hline $\begin{array}{l}\text { No. 565: Local Protectionism and Regional Specialization: Evidence } \\
\text { from China's Industries }\end{array}$ & $\begin{array}{l}\text { Chong-En Bai, Yingjuan Du, } \\
\text { Zhigang Tao, Sarah Y. Tong }\end{array}$ & May 2003 \\
\hline No. 564: Corporate Governance and Market Valuation in China & $\begin{array}{l}\text { Chong-En Bai, Qiao Liu, Joe Lu, } \\
\text { Frank M. Song, and Junxi Zhang }\end{array}$ & May 2003 \\
\hline $\begin{array}{l}\text { No. 563: Revenue Sharing and Control Rights in Team Production: } \\
\text { Theories and Evidence From Joint Ventures }\end{array}$ & $\begin{array}{l}\text { Chong-En Bai, Zhigang Tao, and } \\
\text { Changqi Wu }\end{array}$ & May 2003 \\
\hline $\begin{array}{l}\text { No. 562: Financial Dependence, Stock Market Liberalizations and } \\
\text { Growth }\end{array}$ & Nandini Gupta and Kathy Yuan & May 2003 \\
\hline $\begin{array}{l}\text { No. 561: Growth and Regional Inequality in China During the Reform } \\
\text { Era }\end{array}$ & Derek Jones, Cheng Li and Owen & May 2003 \\
\hline $\begin{array}{l}\text { No. 560: Choice of Ownership Structure and Firm Performance: } \\
\text { Evidence from Estonia }\end{array}$ & $\begin{array}{l}\text { Derek Jones, Panu Kalmi, Niels } \\
\text { Mygind }\end{array}$ & May 2003 \\
\hline No. 559: Explaining Postcommunist Economic Performance & Lawrence P. King & May 2003 \\
\hline $\begin{array}{l}\text { No. 558: Tax Structure and the FDI: The Deterrent Effects of } \\
\text { Complexity and Uncertainty }\end{array}$ & $\begin{array}{l}\text { Kelly Edmiston, Shannon Mudd } \\
\text { and Neven Valev }\end{array}$ & Apr. 2003 \\
\hline No. 557: Provincial Protectionism & Konstantin Sonin & Apr. 2003 \\
\hline $\begin{array}{l}\text { No. 556: Nominal and Real Convergence in Estonia: The Balassa- } \\
\text { Samuelson (dis)connection }\end{array}$ & Balázs Égert & Apr. 2003 \\
\hline $\begin{array}{l}\text { No. 555: Banks-Firms Nexus under the Currency Board: Empirical } \\
\text { Evidence from Bulgaria }\end{array}$ & $\begin{array}{l}\text { Nikolay Nenovsky, Evgeni Peev } \\
\text { and Todor Yalamov }\end{array}$ & Apr. 2003 \\
\hline $\begin{array}{l}\text { No. 554: To Steal or Not to Steal: Firm Attributes, Legal Environment, } \\
\text { and Valuation }\end{array}$ & Art Durnev and E. Han Kim & Apr. 2003 \\
\hline No. 553: Corporate Stability and Economic Growth & $\begin{array}{l}\text { Kathy S. He, Randall Morck and } \\
\text { Bernard Yeung }\end{array}$ & Apr. 2003 \\
\hline $\begin{array}{l}\text { No. 552: So Many Rocket Scientists, So Few Marketing Clerks: } \\
\text { Occupational Mobility in Times of Rapid Technological Change }\end{array}$ & $\begin{array}{l}\text { Nauro F. Campos and Aurelijus } \\
\text { Dabušinskas }\end{array}$ & Mar. 2003 \\
\hline $\begin{array}{l}\text { No. 551: Determinants of Interregional Mobility in Russia: Evidence } \\
\text { from Panel Data }\end{array}$ & $\begin{array}{l}\text { Yuri Andrienko and Sergei } \\
\text { Guriev }\end{array}$ & Feb. 2003 \\
\hline $\begin{array}{l}\text { No. 550: Gross Job Flows in Ukraine: Size, Ownership and Trade } \\
\text { Effects }\end{array}$ & $\begin{array}{l}\text { Jozef Konings, Olga Kupets and } \\
\text { Hartmut Lehmann }\end{array}$ & Mar. 2003 \\
\hline $\begin{array}{l}\text { No. 549: Technology Transfer through FDI in Top-10 Transition } \\
\text { Countries: How Important are Direct Effects, Horizontal and Vertical } \\
\text { Spillovers? }\end{array}$ & $\begin{array}{l}\text { Jože P. Damijan, Mark Knell, } \\
\text { Boris Majcen and Matija Rojec }\end{array}$ & Feb. 2003 \\
\hline $\begin{array}{l}\text { No. 548: Does Foreign Direct Investment Increase the Productivity of } \\
\text { Domestic Firms? In Search of Spillovers through Backward Linkages }\end{array}$ & Beata K. Smarzynska & Mar. 2003 \\
\hline $\begin{array}{l}\text { No. 547: Re-employment Probabilities and Wage Offer Function for } \\
\text { Russian Labor Market }\end{array}$ & Natalia V. Smirnova & Feb. 2003 \\
\hline $\begin{array}{l}\text { No. 546: Democratization's Risk Premium: Partisan and Opportunistic } \\
\text { Political Business Cycle Effects on Sovereign Ratings in Developing } \\
\text { Countries }\end{array}$ & $\begin{array}{l}\text { Steven Block, Burkhard N. } \\
\text { Schrage and Paul M. Vaaler }\end{array}$ & Feb. 2003 \\
\hline $\begin{array}{l}\text { No. 545: Structural Reforms and Competitiveness: Will Europe } \\
\text { Overtake America? }\end{array}$ & Jan Svejnar & Feb. 2003 \\
\hline No. 544: Why the Rich May Favor Poor Protection of Property Rights & Konstantin Sonin & Dec. 2002 \\
\hline $\begin{array}{l}\text { No. 543: Reinvested Earnings Bias, The "Five Percent" Rule and the } \\
\text { Interpretation of the Balance of Payments - With an Application to } \\
\text { Transition Economies }\end{array}$ & $\begin{array}{l}\text { Josef C. Brada and Vladimír } \\
\text { Tomšík }\end{array}$ & Feb. 2003 \\
\hline
\end{tabular}

